\title{
Assessing the Prevalence and Factors Affecting Sexual Harassment Among Female Staffs of a Supermarket in Kathmandu, Nepal
}

\author{
Ira Sharma ${ }^{1}$ and Sangam Lama ${ }^{2}$ \\ ${ }^{1}$ Trichandra College, Tribhuwan University, Nepal \\ ${ }^{2}$ Nepal Institute of Health Sciences College, Purbanchal University, Nepal
}

\begin{tabular}{|c|c|}
\hline ARTICLE INFO & ABSTRACT \\
\hline $\begin{array}{l}\text { Keywords: } \\
\text { Female } \\
\text { Nepal } \\
\text { Sexual harassment } \\
\text { Supermarket } \\
\text { Workplace }\end{array}$ & $\begin{array}{l}\text { This cross-sectional study was carried out to assess the prevalence and } \\
\text { factors affecting sexual harassment (SH) among female staffs of a } \\
\text { supermarket in Kathmandu, Nepal. The data were collected with self- } \\
\text { administered questionnaire from } 170 \text { staffs. Uni-variate (descriptive } \\
\text { detail) and bivariate (statistical detail) analyses were the methods } \\
\text { applied. Among } 24.1 \% \text { of sexually harassed respondents, the most } \\
\text { common was } 15-30 \text { years' age group. Moreover, } 80.5 \% \text { of the victims } \\
\text { were harassed verbally, } 39 \% \text { non-verbally and } 48.8 \% \text { physically. The } \\
\text { harassment occurred either when they were alone (non-verbal } 56.5 \% \text { and } \\
\text { physical } 78.3 \% \text { ) or when the shop was crowded (non-verbal } 29.3 \% \text { and } \\
\text { physical } 88.2 \%) \text {. Most of the victims accepted the problem (non-verbal } \\
55.6 \% \text { and physical } 94.4 \%) \text { due to fear of being fired and social stigma. } \\
\text { Non-verbal (53.8\%) and physical (100\%) harassments mostly occurred } \\
\text { during night shift whereas verbal harassment ( } 63.4 \%) \text { occurred during } \\
\text { day shift. Out of } 6 \text { selected predictors: age, dress, place, shift, perpetrator } \\
\text { and acceptance of the incident, the verbal harassment was statistically } \\
\text { associated with shift ( } 63.6 \% \text { in day, p-val.= } 0.007) \text {, non-verbal } \\
\text { harassment was associated with age ( } 25 \% \text { of age } 15-30 \text { years, p- } \\
\text { val.=0.002) and the physical harassment was statistically associated with } \\
\text { age (35\% of age } 15-30 \text { years, p-val.=0.000), shift (35.0\% at night, p- } \\
\text { val.=0.000), prepatrators ( } 25 \% \text { of age } 15-30 \text { years, p-val.=0.003), } \\
\text { acceptance ( } 40.0 \% \text { due fear of being fired/ social stigma, p-val. }=0.000) \text {. } \\
\text { In order to reduce sexual harassment among female staffs of } \\
\text { supermarkets, there must be awareness programs for all the staff, } \\
\text { advocacy programs against SH for customers and staffs, punishment for } \\
\text { the perpetrators must be legal. }\end{array}$ \\
\hline
\end{tabular}

\section{Introduction}

Violence has been an unpalatable but unalienable of human life before and even after the dawn of civilization. The phenomenon of violence seems to be on rise in all parts of the world. These days, we have been hearing a big hue and cry about \#Me Too, that clears years long misconduct of sexual harassment in different occupational fields (Valbrune, 2018). Mostly women and children are the victims. Harassment is a form of violence which has a common type, the sexual harassment $(\mathrm{SH})$ that typically includes unexpected sexual advances, request of sexual favours, verbal or physical harassment for the sake of sexual pleasure (Paludi \& Barickman, 1991). SH is bully of a sexual nature or unbelievable promise of rewards for sexual favours. Actually, it is an act that is unlawful because of the person's sexual orientation (Kamberi \& Gollopeni, 2015). SH includes several behaviors having a broad range of activities that includes particularly the sexual coloring in our society. Therefore, the behavior that looks relatively

\footnotetext{
*Corresponding Author E-Mail Address: irasg123@gmail.com 
ordinary (such as joking, flirting, sexual assaults and requesting for a date), if are deliberate and repeated are the conducts of SH. SH impacts negatively on an individual's ability to perform job and also creates an intimidating, offensive and humiliating work environment where a person's psychological wellbeing would pay a high economic, social and human cost. Society for Human Resource Management (SHRM) explains that SH can be perpetrated by anyone in the work place including peer, supervisor, subordinate, vendor, customer or contractor (SHRM 2015).

International Trade Union Confideration (ITUC) reports that issue of sexual harassment is estimated around $40-50 \%$ of all working women throughout the world. Additionally, in the worst cases, women commit suicide since these cases make victims impossible to face society and they give up the hope to live. They are mostly kept at a false side, and their complaints might be dismissed. They might lose the due official benefits like promotion prospects, or have to resign in case they raise the voice against perpetrators (ITUC, 2008). Even though anyone can be a victim or a perpetrator, International Labor Organization (ILO) has shown that mostly female and the children are vulnerable to sexual harassment (ILO, 2004).

There are many factors affecting sexual harassment. Violence has connection with patriarchal social structure. Most of the men perceive the 'feminist drive for economic equality or independence' as a threat to their traditional superior role (Baker, 1999). Global report published by World Health Organization (WHO) indicate that about 35\% women worldwide have experienced some form of violence and factors associated with the perpetration of violence are low education, child maltreatment or exposure to violence in the family, use of alcohol/ narcotic drugs, attitudes accepting the violence and gender inequality (WHO, 2016). In Nepal the prevalence of sexual violence is still worse. According to a study report by Nepal Demographic Health Survey (NDHS) report 2011, 12\% of all Nepalese women have ever experienced sexual violence among which young women aged 15-19 are more vulnerable but less likely to report about the experience of sexual violence (NDHS, 2012). The study conducted by ILO (2004) in Kathmandu Valley showed about 54\% of female workers had experienced sexual harassment in work places that included factories, hospitals, private/ government offices, domestic chores, schools etc. However, the super markets, which are continuously growing in cities with majority of the staffs being female, are still unknown about its work environment and safety. Therefore, this study aimed to estimate the prevalence of sexual harassment and identify the factors associated with, in a popular super market of Kathmandu, Nepal.

\section{Materials and Methods}

\subsection{Study Area, Population and Sample}

A cross sectional and quantitative study carried out in a popular supermarket of Kathmandu. All the female staffs working in that super market were the study population from where a fixed sample was chosen purposively.

According to ILO (2004), the prevalence of female sexual harassment at workplace in Nepal was $54 \%$. So, the sample size will be calculated using the formula:

$$
n=Z^{2} p q / d^{2}
$$

where, $n=$ Number of total samples chosen for interview.

$\mathrm{Z}=$ critical value for $95 \%$ confidence interval i.e., 1.96 at standard normal deviation.

$\mathrm{p}=\mathrm{sexual}$ harassment prevalence rate of Nepal $=54 \%=0.54$

$\mathrm{q}=1-\mathrm{p}=0.46$

The margin of error $(\mathrm{d})=5 \%$

Therefore, $\mathrm{d}^{2}=0.0025$

Hence, $\mathrm{n} \approx 149.1$

Additional $15 \%$ allowable error, i.e., $\approx 22$ 
So, total $=149+22=171$

The figure had been rounded off eliminating 1 sample. Therefore, the actual sample size is equal to 170 .

\subsection{Data Collection}

A popular super market in Kathmandu was purposively selected for the study and data collection was carried out during March and April of 2015. Permission was obtained from authorities of supermarket. The staffs were oriented about the study detail and its purpose. The respondents were assured of the confidentiality of their personal information and were free to refuse to participate in the study at any time if they wished. Written consents were taken before the distribution of questionnaire. Only those who were willing to respond were included in the study. The questionnaire was self-administered and a pre testing was done in another shopping mall in $10 \%$ of the selected sample size to check reliability of the tool. Ample amount of literatures were reviewed before preparing the tool to maintain its validity. The questionnaire was prepared in local Nepali language for them to understand and answer well. The convenient sampling method was chosen and the data collection was started from ground floor to the third floor. The data were collected by the researcher herself.

The questionnaire had two parts - first, about the demographic detail of respondents and second, about the SH experienced by them and this was prepared based on A Trade Union Guide for Stopping Sexual Harassment by International Trade Union Confederation (ITUC, 2008). The second part was further divided into three parts:

1. Verbal harassment - Verbal harassment means, making sexual comments, telling shameful jokes, asking about sexual fantasies, insulting or rating someone based on the sex, twisting work discussions into sexual topics, whistling, smacking lips and making kissing sounds, requesting sexual favors in lieu of promotion.

2. Non-verbal harassment - It covers the activities such as displaying vulgar pictures in paper or PC desktop, showing other explicit materials, sending anonymous letters, winking eyes, throwing kisses, blocking her path, starring up and down, showing the filthy gestures and unacceptable body movements at her.

3. Physical harassment - It includes unusual touching, pinching, squeezing, stroking, brushing against someone and any form of physical assault.

\section{Analysis and Results}

The collected data were checked for completeness and consistency. The data were coded and data entry and analysis were done using Statistical Package for Social Science (SPSS) version 16. The univariate analyses were illustrated in frequency table, graphs and charts.

The bivariate analyses were done by Chi square tests or the Fisher exact tests (when at least one of the cells in contingency table contained the values >5) and presented in tables. Following are the results of the study.

\subsection{Univariate Analysis}

Table 1 illustrates the findings on demographic characteristics of the respondents. Out of 170 respondents, $83 \%$ were of age group 15-30, $17 \%$ were of age group 30-45 and out of them 50\% of the respondents were married. Regarding educational status $6 \%$ of the respondents could read only, $1 \%$ had completed secondary level, $11 \%$ had completed School Leaving Certificate (SLC), that is, class 10 in our context and majority of the respondents $(82 \%)$ had completed +2 and above. 
Table 1.

Demographic detail of the respondents

\begin{tabular}{lcc}
\hline & $\begin{array}{c}\text { Frequency } \\
(\mathbf{n = 1 7 0})\end{array}$ & $\begin{array}{c}\text { Percent } \\
(\boldsymbol{\%})\end{array}$ \\
\hline Marital status of respondent & & \\
$\quad$ Married & 85 & 50.0 \\
$\quad$ Unmarried & 85 & 50.0 \\
Age of the respondent & & \\
$\quad$ 15-30 & 140 & 82.4 \\
30-45 & 30 & 17.6 \\
Educational status of respondent & & \\
$\quad$ Can read only & 11 & 6.4 \\
Secondary level & 2 & 1.2 \\
SLC & 18 & 10.6 \\
$\quad+2$ and above & 139 & 81.8 \\
\hline
\end{tabular}

All of 170 respondents had heard about sexual harassment. The Figure 1 shows that out of 170 respondents, $24.1 \%$ of the respondents were sexually harassed.

\section{Prevalence (\%) of Sexual harassment}

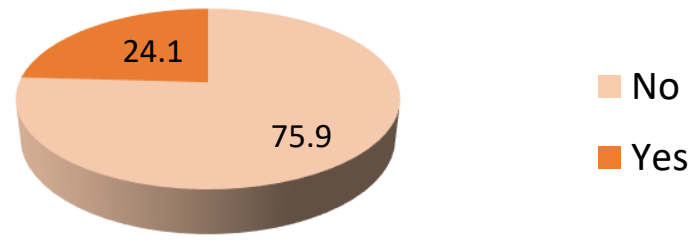

\section{Figure 1.}

Prevalence of sexual harassment

A multiple-choice answer in Figure 2 shows that out of 41 sexually harassed respondents, the highest, $80 \%$ of the respondents were verbally harassed, $49 \%$ of the respondents were physically harassed and the least $39 \%$ were non-verbally harassed.

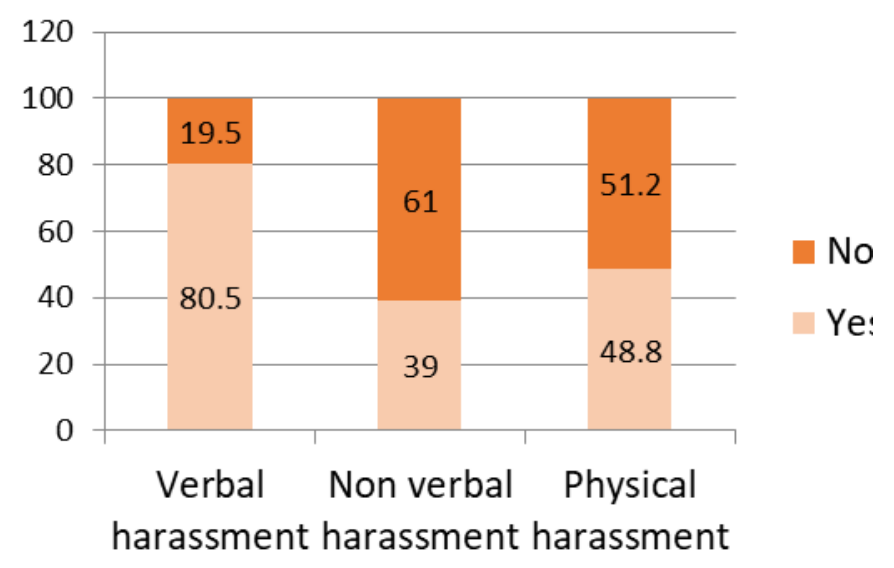

Figure 2.

Prevalence of verbal, non-verbal and physical harassment 


\subsection{Bivariate Analysis}

Six different variables (age, dress used, place of harassment, shift of duty, perpetrator, acceptance of $\mathrm{SH}$ ) were selected for cross tab analysis with binary outcome using Fisher exact test. The Fisher exact test was appropriate here for all the cases since the two-by-two matrix table had less than 5 count in any one of the 4 cells. They were analysed separately for verbal, non-verbal and physical harassments.

\section{Association between verbal harassment and selected variables}

The verbal harassment was significant with only the shift of the day (p-value 0.007) while with other variables it showed no statistical association (Table 2).

Table 2.

Association between verbal harassment and other variables

\begin{tabular}{lcccc}
\hline Description & No (\%) & Yes (\%) & Total & P-value \\
\hline Age of the respondent & & & & \\
$\quad$ 15-30 & $5(15.0)$ & $12(37.0)$ & 17 & \\
30-45 & $11(33.0)$ & $5(15.0)$ & 16 & 0.43 \\
$\quad$ Total & $16(50)$ & $17(50)$ & 33 & \\
Dress used & $1(2.4)$ & $0(0)$ & $1(2.4)$ & 1 \\
$\quad$ Uniform of BBSM & $6(17.1)$ & $26(80.5)$ & $32(97.6)$ & \\
$\quad$ Casual wear & $7(19.5)$ & $26(80.5)$ & 33 & \\
$\quad$ Total & & & & \\
Place of sexual harassment & $3(9.8)$ & $10(30.5)$ & $13)$ & 0.698 \\
$\quad$ While going to toilet & $3(9.8)$ & $17(50.5)$ & 20 & \\
$\quad$ While providing customer service & $6(19.6)$ & $27(80.4)$ & 33 & \\
$\quad$ Total & & & & \\
Shift of the duty & 0 & $21(63.6)$ & 21 & \\
$\quad$ Day & $6(18.2)$ & $6(18.2)$ & 12 & 0.007 \\
$\quad$ Night & $6(18.2)$ & $27(81.8)$ & 33 & \\
$\quad$ Total & & & & \\
Perpetrator & $5(15.2)$ & $10(30.3)$ & 15 & \\
$\quad$ Customers & $1(3.0)$ & $17(51.5)$ & 18 & 0.115 \\
$\quad$ Staffs & $6(18.2)$ & $27(81.8)$ & 33 & \\
$\quad$ Total & & & & \\
Acceptance & $0(0)$ & $16(48.5)$ & 16 & \\
$\quad$ Ignoring incidents & $6(18.2)$ & $11(33.3)$ & 17 & 0.267 \\
$\quad$ Fear of being fired/ social stigma & $6(18.2)$ & $27(81.8)$ & 33 & \\
$\quad$ Total & & & & \\
\hline
\end{tabular}

Similarly, non-verbal harassment was found associated with only age (p-value $=0.002)$ and 1530 years' age group was more prone to harassment. Rest of the variables showed no statistical association with the verbal harassment (Table 3).

Table 3.

Association between non-verbal harassment and the other variables

\begin{tabular}{lcccc}
\hline Description & No $(\%)$ & Yes $(\%)$ & Total & P-value \\
\hline Age of the respondent & & & & \\
$\quad 15-30$ & $4(25.0)$ & $4(25.0)$ & 8 & 0.002 \\
$30-45$ & $6(37.5)$ & $2(12.5)$ & 8 & \\
$\quad 10(62.4)$ & $6(37.5)$ & 16 & \\
$\begin{array}{l}\text { Total } \\
\quad \text { uniform of BBSM }\end{array}$ & $1(6.2)$ & $0(0)$ & 1 & 1.000 \\
\hline
\end{tabular}




\begin{tabular}{lcccc}
\hline Description & No $(\%)$ & Yes $(\%)$ & Total & P-value \\
\hline casual wear & $9(56.2)$ & $6(37.5)$ & 15 & \\
$\quad$ Total & $10(62.4)$ & $6(37.5)$ & 16 & \\
Place of sexual harassment & & & & \\
$\quad$ While going to toilet & $5(31.3)$ & $3(18.7)$ & 8 & 0.573 \\
$\quad$ While providing customer service & $5(31.3)$ & $3(18.7)$ & 8 & \\
$\quad$ Total & $10(62.6)$ & $6(37.4)$ & 16 & \\
Shift of the duty & & & & \\
$\quad$ Day & $8(50)$ & $3(18.75)$ & 11 & \\
$\quad$ Night & $2(12.5)$ & $3(18.75)$ & 5 & 0.185 \\
$\quad$ Total & $10(62.5)$ & $6(37.3)$ & 16 & \\
Perpetrator & & & & \\
$\quad$ Customers & $2(12.5)$ & $1(6.25)$ & 3 & \\
$\quad$ Staffs & $8(50.0)$ & $5(31.25)$ & 13 & 0.309 \\
$\quad$ Total & $10(62.5)$ & $6(37.5)$ & 16 & \\
Acceptance & & & & \\
$\quad$ Ignoring incidents & $7(43.7)$ & $1(6.2)$ & 8 & \\
$\quad$ Fear of being fired/social stigma & $3(18.8)$ & $5(31.8)$ & 8 & 0.055 \\
$\quad$ Total & $10(62.5)$ & $16(37.5)$ & 16 & \\
\hline
\end{tabular}

Moreover, the association of physical harassment was found significant with age (pvalue $=0.000)$, shift $(\mathrm{p}$-value $=0.000)$, perpetrator $(\mathrm{p}$-value $=0.008)$ and the acceptance by the victims ( $\mathrm{p}$-value $=0.000)$ (Table 4).

Table 4.

Association between physical harassment and other variables

\begin{tabular}{lcccc}
\hline Description & No $(\%)$ & Yes $(\%)$ & Total & P-value \\
\hline Age of the respondent & & & & \\
$15-30$ & $3(15.0)$ & $7(35.0)$ & 10 & 0.000 \\
$30-45$ & $7(35.0)$ & $3(15.0)$ & 10 & \\
$\quad$ Total & $10(50.0)$ & $10(50.0)$ & 20 & \\
Dress used & & & & \\
$\quad$ Uniform of BBSM & $0(0)$ & $1(5.0)$ & 1 & 0.488 \\
$\quad$ Casual wear & $10(52.5)$ & $9(45.0)$ & 19 & \\
$\quad$ Total & $10(52.5)$ & $10(50.5)$ & 20 & \\
Place of sexual harassment & & & & \\
$\quad$ While going to toilet & $5(25.0)$ & $5(25.0)$ & 10 & 1 \\
$\quad$ While providing customer service & $5(25.0)$ & $5(25.0)$ & 10 & \\
$\quad$ Total & $10(50)$ & $10(50.0)$ & & \\
Shift of the duty & & & & \\
$\quad$ Day & $0(0.0)$ & $0(0.0)$ & 0 & 0.000 \\
$\quad$ Night & $0(0.0)$ & $20(100.0)$ & 20 & \\
$\quad$ Total & $0(0.0)$ & $20(100.0)$ & 20 & \\
Perpetrator & $1(5.0)$ & $3(15.0)$ & 4 & 0.003 \\
$\quad$ Customers & $9(45.0)$ & $7(35.0)$ & 16 & \\
$\quad$ Staffs & $10(50.0)$ & $10(50.0)$ & 20 & \\
$\quad$ Total & & & \\
Acceptance & $10(50.0)$ & $1(5.0)$ & 11 & 0.000 \\
$\quad$ Ignoring incidents & $1(5.0)$ & $8(40.0)$ & 9 & \\
$\quad$ Fear of being fired/social stigma & $10(55.0)$ & $20(45.0)$ & 20 & \\
$\quad$ Total & & & \\
\hline
\end{tabular}




\section{Discussion}

The study revealed that the prevalence of $\mathrm{SH}$ at shopping mall is quite high as compared to overall prevalence in working sectors like carpet industries, garment industries, hospitals, schools and domestic chores that reported, the sexually harassed females aged above 15 years in the workplace in past five years (ILO, 2004) was 54\%. Also, the shopping malls have late shift duties for staffs that caused higher prevalence of $\mathrm{SH}$. A research in six carpet factories in Kathmandu valley showed 52\% were sexually harassed by co-workers (Dhakal, 2009). The result observed in a research of national sexual harassment in Australia by Australian Human Right Commission (AHRC) showed that, in the past five years, one fifth of the people above 15 years of age were sexually assaulted in the workplace (AHRC, 2012). Coherently, this study showed the common perpetrators were the coworkers in all three forms of harassments. Additionally, this study revealed that the verbal form of harassment was more common than other forms of harassments. Here, four out of five experienced verbal harassment, two out of three were non verbally harassed and nearly half of the total victims encountered the physical harassment. Chappel and Martino (2006) says that verbal form of SH was the most common one, that was experienced by nearly two-third of the female employee. While females of age group 10-30 were more prone to SH. Among the victims one third were harassed physically and nearly fifty percentage were harassed non verbally and three fourth were harassed verbally. This difference in prevalence of each type of harassment with ours might be due to variation in the context and work environment.

This study showed that all of the female staff experienced the physical harassment in night shift duty and the association was statistically significant. Boghani (2015) reports similar cases as ours that in two thirds of those women who worked at night shift in an industry were raped or sexually assaulted at work where the victims were afraid or ashamed to go to the authorities for complaint. It might be possible that during night time, the perpetrators feel easy to hide or escape and handle the victims when they are lonely and free. Similarly, Byfield (2012) showed that there was no statistical association between the place of SH and the dress they wore in workplace. Actually, the perpetrators look for signs of passiveness and submissiveness of the victims before intending to harass and no female would dress themselves for being raped. These results looked consistent with that of ours.

The study shows there is association between acceptance by the victim with both non-verbal harassment and physical harassment due to fear of being fired and social stigma. Similar results were revealed by the study that many of such cases are not taken to the police that save the criminals from getting prosecuted. An important factor for not reporting the cases of sexual assault is the fear of reprisal and getting oneself in trouble. This study also shows there is association between number of staffs present with both physical harassment and non-verbal harassment. Majority of staffs were alone while they were physically and non-verbally harassed. Similar results were found in Boghani's (2015) report where the victims who were alone in their duty were especially vulnerable for sexual harassment. This study shows that the staffs were the common perpetrators than the customers which was consistent with some studies where the perpetrators were typically the co-workers (Johnson, 1994).

However, the study limits the area to only a single shopping mall, and does not speak about the need of legal provisions of preparators or the practical loopholes the authorities have blindfolded about the event.

\section{Conclusion}

The prevalence of $\mathrm{SH}$ as estimated in this study is quite high among the staffs of a supermarket in Kathmandu, Nepal and it is a serious issue. Above that, staffs working at night shift were more vulnerable to physical assault, which needs immediate action for duty staffs' safety. It is recommended that concerned authorities need to provide a safe work environment for females 
at any shift they work as soon as possible. The further study can be focused on the SH practices at various other kind of workplaces and methods to minimize it, so that the female staffs need not fear and suffer of such misfortune during work hours.

\section{Acknowledgements}

Authors would like to thank all the participants, the staffs and authorities of the supermarket who accepted and provided valuable information for this research purpose. We are grateful to Nepal Institute of Health Sciences College for providing us the platform to bring this work to this form.

\section{Declaration of Conflicting Interests}

Authors declare no any conflict of interest with respect to this research work and its publication.

\section{References}

Australian Human Rights Commission (AHRC). 2012. "Working without fear: results of the 2012 sexual harassment national telephone survey". Australian Human Rights Commission. Australia. Retrieved from https://www.humanrights.gov.au/sites/default/files/content/sexualharassment/survey/SHSR_2012 $\% 20 \mathrm{Web} \% 20$ Version\%20Final.pdf

Becker, M. 1999. "Patriarchy and Inequality: Towards a Substantive Feminism". University of Chicago Legal Forum. Vol. 1999 (1), article no. 3. Retrieved from https://chicagounbound.uchicago.edu/cgi/viewcontent.cgi?article=1266andcontext=uclf

Boghani, P. 2015. "By the Numbers: The Magnitude of Rape and Sexual Assault". Retrieved from http://www.pbs.org/wgbh/frontline/article/by-the-numbers-the-magnitude-of-rape-and-sexualassault/.

Byfield, B. 2012. "Harassment and clothing". Off the Wall. Retrieved from https://brucebyfield.com/2012/08/13/harassment-and-clothing/.

Chappell, D. and Vittorio, D.M. 2006. Violence at work. 3rd edn. International Labor Organization (ILO) Office. Geneva.

Dhakal, G. 2009. "Women's experience of sexual harassment in carpet factories". Journal of Nepal Health Research Council, 7(15): 98-102.

International Labor Organization (ILO). 2004. Sexual Harassment at the Workplace in Nepal. International Labour Office. Kathmandu Office, Nepal. Retrieved from http://www.ilo.org/wcmsp5/groups/public/@asia/@ro-bangkok/@ilokathmandu/documents/publication/wcms_113780.pdf

International Trade Union Confideration (ITUC). 2008. "Stopping sexual harashment at work- A trade union guide". International trade union confideration. Brussels, Belgium. Retrieved from https://www.ituc-csi.org/IMG/pdf/Harcelement_ENG_12pgs_BR.pdf .

Johnson, H. 1994. "Work-related sexual harassment Perspectives on Labour and Income". Statistics Canada. Vol. 6(4). Article No. 1. Retrieved from http://www.statcan.gc.ca/pub/75-001x/1994004/1561-eng.pdf.

Kamberi, F. and Gollopeni, B. 2015. "The Phenomenon of Sexual Harassment at the Workplace in Republic of Kosovo". International Review of Social Sciences. Vol. 3(12): 580-592

Nepal Demographic Health Survey (NDHS). 2012. Nepal Demographic Health Survey Report, 2011. Ministry of Health and Population (MOHP) [Nepal], New ERA, and ICF International Inc. 2012. Kathmandu, Nepal. Retrieved from https://dhsprogram.com/pubs/pdf/fr257/fr257[13april2012].pdf 
Paludi, M. A. and Barickman R. B. (1991). Academic and workplace sexual harassment. Sunny Press. New York, US. ISBN10: 0-7914-0830-2.

Society for Human Resource Management (SHRM). 2015. EEO: Sexual Harassment: What are the different types of sexual harassment? Retrieved from https://www.shrm.org/resourcesandtools/tools-and-samples/hr$\mathrm{qa} /$ pages/typesofsexualharassment.aspx.

Valbrune, M. 2018. \#MeToo: A Practical Guide to Navigating Today's Cultural Workplace Revolution. CreateSpace (Independent Publishing Platform). California, USA.

World Health Organization (WHO). 2016. Violence against women. World Health Organization. Fact sheet of Media Center. Retrieved from http://www.who.int/mediacentre/factsheets/fs239/en/ 